\begin{tabular}{l} 
Journal of Business School \\
$2019,2(5): 1-11$ \\
DOI: $10.26677 / \mathrm{TR} 1010.2019 .118$ \\
\hline 1
\end{tabular}

\title{
The Risk Level of Viet Nam Listed Hotel, Tourism and Entertainment Industry After The Global Crisis 2009-2011
}

\author{
Dinh Tran Ngoc Huy \\ MBA, Ecocomic Faculty, Binh Duong University Viet nam - GSIM, International \\ University of Japan, Japan, dtnhuy2010@gmail.com
}

\begin{abstract}
This paperwork gives some quantitative results based on evaluating the market risk of the listed firms in the Viet nam tourism industry (also including tourism, hotel and entertainment groups), esp. after the financial crisis 2009-2011. First, by using quantitative and analytical methods to estimate asset and equity beta of total 22 listed companies in Viet Nam tourism industry with a proper traditional model, we found out that the beta values, in general, for many institutions are acceptable. Second, we recognized that the risk level, measured by equity and asset beta mean, decreases when using leverage (asset beta mean value of 0,403 decreasing from equity beta mean of 0,588 ). Third, by changing leverage in 3 scenarios, we recognized the dispersion of risk level, measured by equity beta var of 0,892 , in the entertainment industry is the highest, compared to the rest 2 industries. Finally, this paper provides some outcomes that could provide companies and government more evidence in establishing their policies in governance.
\end{abstract}

Keywords: Equity Beta, Financial Structure, Financial Crisis, Risk, External Financing, Tourism Industry

\section{Introduction}

Financial development has positive effect for the economic growth, throughout many recent years, and Viet Nam hotel, tourism, and entertainment industry (called tourism industry in this paperwork) is considered as one of active economic sectors in local financial markets, which has some positive effects for the economy. The tourism industry is selected because until now there is no research published with the same scope.

This paper is organized as follow. The research issues and literature review will be covered in next sessions 2 and 3, for a short summary. Then, methodology and conceptual theories are introduced in session 4 and 5. Session 6 describes the data in empirical analysis. Session 7 presents empirical results and findings. Next, session 8 covers the analytical results. Then, session 9 presents empirical results and session 10 presents analysis of risk. Lastly, session 11 shows discussion and session 12 will conclude with some policy suggestions. This paper also supports readers with references, exhibits and relevant web sources. 


\section{Research Issues}

We mention some issues on the estimating of impacts of external financing on beta for listed tourism industry companies in Viet Nam stock exchange as following:

Issue 1: Whether the risk level of tourism industry firms after the crisis 2009-2011 increase or decrease so much.

Issue 2: Whether the disperse distribution of beta values become large after the crisis 2009-2011 in the tourism industry.

\section{Literature review}

Fama, Eugene F., and French, Kenneth R., (2004) also indicated in the three factor model that "value" and "size" are significant components which can affect stock returns. They also mentioned that a stock's return not only depends on a market beta, but also on market capitalization beta. The market beta is used in the three factor model, developed by Fama and French, which is the successor to the CAPM model by Sharpe, Treynor and Lintner.

As Luis E. Peirero (2010) pointed, the task of estimating cost of equity in emerging markets is more difficult because of problems such as collecting data in short periods. Then, Velez-Pareja (2011) referred to the lack of inadequate information on the stock market in emerging countries may undermine beta and relevant formulas. Marcin, Mariusz, Marek, and Karol (2012) mentioned that the reliability and fitness of calculated betas are relevant to the valuation and investment of investors in merging markets.

Umar (2011) found that firms which maintain good governance structures have leverage ratios that are higher (forty-seven percent) than those of firms with poor governance mechanisms per unit of profit. Chen et all (2013) supported regulators' suspicions that over-reliance on shortterm funding and insufficient collateral compounded the effects of dangerously high leverage and resulted in undercapitalization and excessive risk exposure for Lehman Brothers. The model reinforces the importance of the relationship between capital structure and risk management. Then, Alcock et all (2013) found evidence that leverage cannot be viewed as a long-term strategy to enhance performance, but in the short term, managers do seem to add significantly to fund excess returns by effectively timing leverage choices to the expected future market environment. And Gunaratha (2013) revealed that in different industries in Sri Lanka, the degree of financial leverage has a significant positive correlation with financial risk.

Finally, financial leverage can be considered as one among many factors that affect business risk of consumer good firms.

\section{Conceptual theories}

\section{Determinants of Equity and Asset Beta}

Financial development and economic growth are positively interrelated. The interaction between these two (2) fields can be considered as a circle, in which good financial development causes economic growth and vice versa.

In financial markets, systematic risk relates to the overall risk of the whole market, is affected by some factors such as: interest rate fluctuations or economic crisis, can not be avoided by diversification, and is measured by a financial metric, beta which is also called systemic risk.

Another application of beta is that it is used in the Capital asset pricing model (CAPM) to value a firm before making an M\&A and for pricing assets. 
When an investor decides to make an investment in a single company and in a specific stock market, he or she will think of how much risk of the investment. Or what is the beta value of the stock or investment? This research will answer that question.

\section{Methodology}

For calculating systemic risk results and leverage impacts, in this study, we use the live data during the crisis period 2007-2011 from the stock exchange market in Viet Nam (HOSE and HNX and UPCOM).

In this research, analytical research method is used, philosophical method is used and specially, historical analysis method is used. Analytical data is from the situation of listed tourism industry firms in VN stock exchange and curent tax rate is $25 \%$.

Generally speaking, quantitative method is mainly used in this study whith a note that risk measure asset beta is mainly derive from equity beta and financial leverage.

Finally, we use the results to suggest policy for both these enterprises, relevant organizations and government.

\section{General Data Analysis}

Through the analysis of 22 firms in categories of industries: hotel, tourism and entertainment companies groups, the mean of equity beta is about 0,588 and that of asset beta is about 0,403 (lower). This shows us the effectiveness of using financial leverage to reduce the overall riskiness of the 3 industries. And these data are acceptable values during the crisis. While there is only a small difference in beta mean values (or just 0,185 ), the difference in beta max values is bigger (around 0,479).

In addition to, there is a difference in the sample variance of asset and equity beta values. The sample variance of asset beta is lower $(0,37)$, while that of equity beta is a little bit higher $(0,54)$, with a gap of 0,18 . This shows us, once again, that the effectiveness of using financial leverage has decreased the systemic risk for the whole industry.

Beside, max equity beta value is up to 2,035 that is a little bit high, compared to max asset beta value is just 1,555 that is acceptable. The below table 2 shows us that a few companies still has larger risk exposure than most of the others.

And values of equity beta varies in a range from 2,035 (max) to $-1,072(\mathrm{~min})$ and that of asset beta varies in a range from 1,555 (max) to $-0,922(\mathrm{~min})$. There are 2 listed companies with beta lower than $(<) 0$ showing the stock return moving opposite to the market index (see table 2 below). Therefore, if beta of debt is assumed to be zero (0), the company's financial leverage contributes to a decrease in the market risk level.

Last but not least, there is a smaller difference between equity and asset beta variance values which is just 0,17 , compared to the relatively higher gap between max equity and max asset beta values, which is about 0,47 . So, there is not quite big effect from financial leverage on the gap between company's beta variance values.

Generally speaking, there is $68 \%$ of listed firms in 3 industries with acceptable beta values lower than $(<) 1$ and higher than $(>) 0$ whereas there is $23 \%$ of these listed firms having beta higher than $(>) 1$ and having more market risks. This number is somewhat high. And $68 \%$ of firms with acceptable beta values uses more financial leverage than the $23 \%$ (36,9\% compared to $26,4 \%$ ).

Table 1 - Estimating beta results for Three (3) Viet Nam Listed Tourism, Hotels and Entertainment Companies Groups (as of Dec 2012) (source: Viet Nam stock exchange data) 


\begin{tabular}{|l|c|c|c|}
\hline $\begin{array}{l}\text { Statistic } \\
\text { results }\end{array}$ & $\begin{array}{c}\text { Equity } \\
\text { beta }\end{array}$ & Asset beta (assume debt beta = 0) & Difference \\
\hline MAX & 2,035 & 1,555 & 0,4797 \\
\hline MIN & $-1,072$ & $-0,922$ & $-0,1497$ \\
\hline MEAN & 0,588 & 0,403 & 0,1849 \\
\hline VAR & 0,5445 & 0,3671 & 0,1774 \\
\hline \multicolumn{4}{|c|}{ Note: Sample size : 22} \\
\hline
\end{tabular}

Table 2 - The number of companies in research sample with different beta values and financial leverage

\begin{tabular}{|c|c|c|c|}
\hline Equity Beta & $\begin{array}{c}\text { No. of } \\
\text { firms }\end{array}$ & Financial leverage (average) & Ratio \\
\hline$<0$ & 2 & $17,57 \%$ & $9 \%$ \\
\hline $0<$ beta $<1$ & 15 & $36,90 \%$ & $68 \%$ \\
\hline Beta $>1$ & 5 & $26,38 \%$ & $23 \%$ \\
\hline total & 22 & $32,8 \%$ & $100 \%$ \\
\hline
\end{tabular}

\begin{tabular}{|c|c|c|c|}
\hline Asset Beta & $\begin{array}{c}\text { No. of } \\
\text { firms }\end{array}$ & Financial leverage (average) & Ratio \\
\hline$<0$ & 2 & $17,57 \%$ & $9 \%$ \\
\hline $0<$ beta $<1$ & 16 & $38,19 \%$ & $73 \%$ \\
\hline Beta $>1$ & 4 & $18,59 \%$ & $18 \%$ \\
\hline total & 22 & $32,8 \%$ & $100 \%$ \\
\hline
\end{tabular}

\section{Empirical Research Findings and Discussion}

\section{A-Tourism listed companies group}

During the crisis period 2007-2011, the market for these companies still exists, but has certain difficulties. The market for these firms has been affected because good prices increase. However, the prices for tourism ticket are still acceptable.

The below tables 3 and 4 show us there are 10 listed firms in this industry category whose values of equity and asset beta mean are around 0,76 and 0,53 , accordingly.

These values show a low and acceptable un-diversifiable risk. When the economy starts to open and enters WTO, the market demand for tourism or business combined with tourism is still obvious.

Furthermore, the variance of equity and asset beta of the sample group equals to 0,75 and 0,56 accordingly that are higher than the entire sample beta var $(0,54$ and 0,37$)$, indicating that the beta values are more dispersed. In fact, the impacts from the global financial crisis will take place on the tourism industry first and before it influences on the 2 other industries: hotel and entertainment. And the impact from using financial leverage makes these beta values fluctuate a little bit more from the sample beta mean.

Beside, we note that equity beta values of these 10 listed firms in this tourism category are a little higher than those of firms in the rest two (2) groups. This is one characteristic of the tourism industry during the crisis period. Among three (3) industries, the non-diversifiable risk of tourism group companies is a bit higher than those of the rest two groups. 
Finally, the table 3 and 4 give us equity and asset beta mean values lower than $(<) 1$ which are acceptable numbers.

Table 3 - Estimating beta results for Viet Nam Listed Tourism Companies (as of Dec 2012) (source: Viet Nam stock exchange data)

\begin{tabular}{|r|l|r|r|l|r|}
\hline $\begin{array}{c}\text { Order } \\
\text { No. }\end{array}$ & $\begin{array}{c}\text { Company } \\
\text { stock code }\end{array}$ & $\begin{array}{c}\text { Equity } \\
\text { beta }\end{array}$ & $\begin{array}{c}\text { Asset beta } \\
\text { (assume debt } \\
\text { beta = 0) }\end{array}$ & \multicolumn{1}{c|}{ Note } & $\begin{array}{c}\text { Financial } \\
\text { leverage (F.S } \\
\text { reports) }\end{array}$ \\
\hline 1 & CTC & 0,290 & 0,092 & & $68,1 \%$ \\
\hline 2 & DLC & 0,475 & 0,281 & DLV as comparable & $40,7 \%$ \\
\hline 3 & DLV & 0,719 & 0,264 & PGT as comparable & $63,3 \%$ \\
\hline 4 & FDT & 0,965 & 0,496 & PGT as comparable & $60,7 \%$ \\
\hline 5 & HOT & 1,489 & 1,303 & PGT as comparable & $15,6 \%$ \\
\hline 6 & PDC & 2,035 & 1,445 & & $36,2 \%$ \\
\hline 7 & PGT & 1,648 & 1,555 & & $7,1 \%$ \\
\hline 8 & TCT & 0,660 & 0,607 & & $10,1 \%$ \\
\hline 9 & TTR & $-1,060$ & $-0,922$ & & $16,3 \%$ \\
\hline 10 & MAS & 0,382 & 0,190 & & $62,6 \%$ \\
\hline \multicolumn{7}{r}{} & & & Average & $38,1 \%$ \\
\hline
\end{tabular}

Table 4 - Statistical results for Vietnam listed Tourism companies

\begin{tabular}{|l|c|c|c|}
\hline Statistic results & $\begin{array}{c}\text { Equity } \\
\text { beta }\end{array}$ & Asset beta (assume debt beta = 0) & Difference \\
\hline MAX & 2,035 & 1,555 & 0,4797 \\
\hline MIN & $-1,060$ & $-0,922$ & $-0,1382$ \\
\hline MEAN & 0,760 & 0,531 & 0,2289 \\
\hline VAR & 0,7508 & 0,5602 & 0,1906 \\
\hline \multicolumn{3}{|c|}{ Note: Sample size : 10} \\
\hline
\end{tabular}

\section{B- Hotel listed companies group}

In a developing economy such as Viet Nam, one of countries with high security and peace, the demand comes from business, community and from international visitors is definitely established and potential because of the public need although it may be affected the financial crisis. The highest demand will be in the last months of a fiscal year for hotels.

The Table 5 below shows us the equity and asset beta mean of 7 listed hotel companies, with values of 0,418 and 0,307 , accordingly. This means the risk is low and acceptable in this category. Moreover, the max equity beta and asset beta values are 1,085 and 0,586 which are quite good numbers, indicating acceptable riskiness in the industry.

Compared to the equity/asset beta values in the entertainment industry, those of the hotel industry are a little lower. It reflects a lower level of systemic risk and maintains the investor confidence of business operation of this industry, and also indicates the good effect from using financial leverage.

Besides, the variance of beta values among these 7 firms is quite small, from 0,09 to 0,02 for equity and asset beta, accordingly. 
Among 3 groups, this is the group whose value of equity beta mean is the smallest.

Please refer to Exhibit 2 for more information.

Table 5 - Statistical results for Vietnam listed Hotel companies

\begin{tabular}{|l|l|l|l|}
\hline $\begin{array}{l}\text { Statistic } \\
\text { results }\end{array}$ & $\begin{array}{l}\text { Equity } \\
\text { beta }\end{array}$ & $\begin{array}{l}\text { Asset beta } \\
\text { (assume debt } \\
\text { beta = 0) }\end{array}$ & Difference \\
\hline MAX & 1,085 & 0,586 & 0,4995 \\
\hline MIN & 0,181 & 0,131 & 0,0508 \\
\hline MEAN & 0,418 & 0,307 & 0,1106 \\
\hline VAR & 0,0924 & 0,0231 & 0,0693 \\
\hline Note: Sample size $: 12$ \\
\hline
\end{tabular}

\section{C- Entertainment listed companies group}

Among 3 groups, this is the group with the smallest number of listed firms (sample size $=5$ ) and with the $2^{\text {nd }}$ lowest equity beta value of about 0,48 . We can see that the using of leverage has influenced these listed firms' risk a bit more than the hotel industry when we compare the difference between equity/asset beta mean values in these 2 industries.

Different from firms in the other industries, 5 listed entertainment firms has the highest equity and asset beta var values, estimated at 0,9 and 0,56 , which implies there is a more dispersion in market risk among firms in this industry category.

While equity and asset beta mean values are acceptable, around 0,481 and 0,280 accordingly, the max values of equity/asset beta is a little high, about 1,509 and 1,216, accordingly but are still not so high.

The equity and asset beta values are distributed in a longer range, from 1,509 to -1,072, and from 1,216 to $-0,819$, compared to those of hotel group. Last but not least, the decrease in asset beta mean value (or the difference of 0,2012 ) indicates the effectiveness of using financial leverage.

Please refer to Exhibit 3 for more information.

Table 6 - Statistical results for Vietnam listed Entertainment companies

\begin{tabular}{|l|c|c|c|}
\hline $\begin{array}{l}\text { Statistic } \\
\text { results }\end{array}$ & $\begin{array}{c}\text { Equity } \\
\text { beta }\end{array}$ & $\begin{array}{c}\text { Asset beta } \\
\text { (assume debt } \\
\text { beta = 0) }\end{array}$ & Difference \\
\hline MAX & 1,509 & 1,216 & 0,2929 \\
\hline MIN & $-1,072$ & $-0,819$ & $-0,2525$ \\
\hline MEAN & 0,481 & 0,280 & 0,2012 \\
\hline VAR & 0,8920 & 0,5563 & 0,3357 \\
\hline \multicolumn{4}{|c|}{ Note: Sample size : 5} \\
\hline
\end{tabular}

\section{Comparison among 3 groups of tourism, hotel and entertainment companies}

In the below chart, we can see among the 3 groups, equity beta value of the hotel group is the lowest $(0,418)$ while asset beta value of the entertainment group is the lowest $(0,28)$. Assuming debt beta is 0 , financial leverage has helped many listed firms in these industries lower the undiversifiable risk.

Additionally, we see the asset beta mean value of tourism group has certain difference, compared to that of 2 other groups and lower than $(<) 0,6$. Next, we can recognize from the chart that, the risk in the tourism industry higher than those in the other 2 industries. 
Last but not least, from the calculated results, variance of equity and asset beta in the 3 industries are lower than 0,9 , which are acceptable. In number, equity beta var varies from 0,00 (hotel) to 0,9 (entertainment) and asset beta var varies from 0,02 (hotel) to 0,56 (entertainment) which are not so high under the effectiveness of leverage.

Chart 1 - Statistical results of three (3) groups of 22 listed VN tourism, hotel and entertainment firms during/after the crisis period 2007-2011

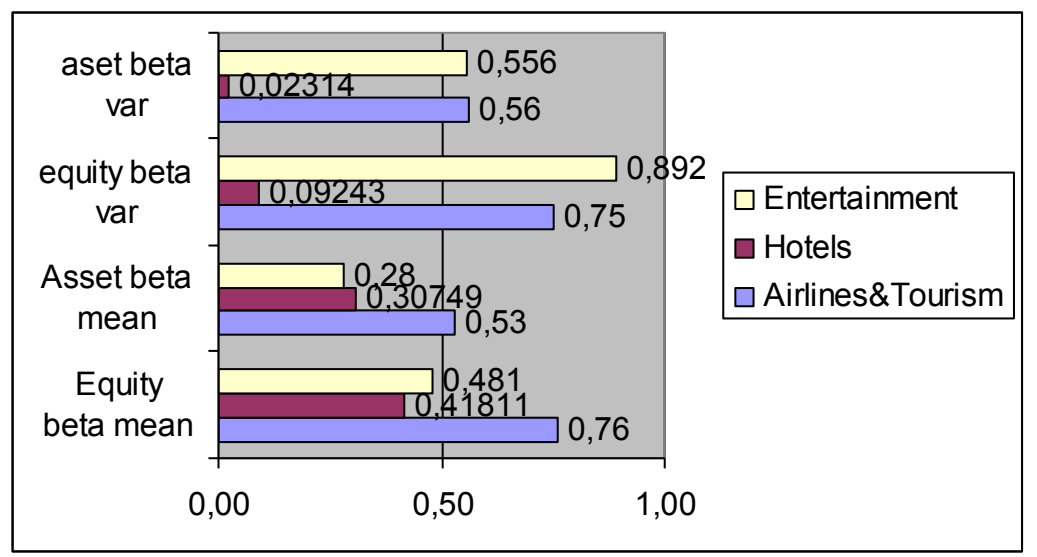

(source: Viet Nam stock exchange 2012)

\section{Empirical results}

In entertainment industry, asset beta mean reach the lowest value $(0,28)$ whereas asset beta var reaches maximum $(0,56)$, compared to the rest 2 cases.

In hotel industry, asset beta mean reach medium value $(0,31)$ whereas asset beta var reaches minimum $(0,023)$, compared to the rest 2 cases.

And finally, in airline\&tourism industry, asset beta mean reach maximum value $(0,53)$ while asset beta var reaches maximum value $(0,56)$, compared to the rest 2 cases.

\section{Risk analysis}

In short, the more debt the firm uses, the more risk it takes. Beside, the increasing interest on loans might drive the earning per share (EPS) lower.

However, the financial leverage becomes worthwhile if the cost of additional financial leverage is lower than the additional earnings before taxes and interests (EBIT) and the risk level could be reduced. Considering risk vs. return, FL becomes a decisional variable for managers. And the maximum risk that a firm accepts will ask for the maximum financial leverage.

\section{Discussion}

Looking at exhibit 5, it is noted that comparing to beta results of construction industry, asset and equity beta mean of tourism industry group are lower than those of construction industry. And the risk dispersion in entertainment industry (shown by equity beta var) is also higher than that in construction industry.

\section{Conclusion and Policy suggestion}

In general, the government has to consider the impacts on the mobility of capital in the markets when it changes the macro policies. Beside, it continues to increase the effectiveness of building the legal system and regulation supporting the plan of developing tourism market. The Ministry of Finance continues to increase the effectiveness of fiscal policies and tax policies 
which are needed to combine with other macro policies at the same time. The State Bank of Viet Nam continues to increase the effectiveness of capital providing channels for tourism companies as we could note that in this study when using leverage, the risk level decreases $(<$ $0,6)$ much as well as the asset beta var $(<0,6)$.

Furthermore, the entire efforts among many different government bodies need to be coordinated.

Finally, this paper suggests implications for further research and policy suggestion for the Viet Nam government and relevant organizations, economists and investors from current market conditions.

\section{REFERENCES}

Alcock J, Baum A, Colley N, Steiner E. (2013). The Role of Financial Leverage in the Performance of Private Equity Real Estate Funds. SSRN Working Paper

Bijlsma MJ, Boone J, Zwart G. (2012). Competition for Traders and Risk. CEPR Discussion Paper No.DP8816.

Chen RR, Chidambaran NK, Imerman MB, Sopranzetti BJ. (2013). Liquidity, Leverage, and Lehman: A Structural Analysis of Financial Institutions in Crisis. Fordham School of Business Research Paper No.2279686.

Dimitrov V, Jain PC. (2006). The Value Relevance of Changes in Financial Leverage. SSRN Working Paper.

Eugene FF, French KR. (2004). The Capital Asset Pricing Model: Theory and Evidence. Journal of Economic Perspectives.

Gunaratha V. (2013). The Degree of Financial Leverage as a Determinant of Financial Risk: An Empirical Study of Colombo Stock Exchange in Sri Lanka. 2nd International Conference on Management and Economics Paper.

Huy DTN. (2013). Estimating Beta of Viet Nam Listed Public Utilities, Natural Gas and Oil Company Groups During and After The Financial Crisis 2007-2011. Economic and Business Review. (15) $1: 57-71$

Maia MV. (2010). Cash-Flow Risks, Financial Leverage and the Cross Section of Equity Returns. SSRN Working Paper.

Mamun MAA. (2013). Performance Evaluation of Prime Bank Limited in Terms of Capital Adequacy. Global Journal of Management and Business Research. (13)9: 26-29.

Ovat OO. (2013). Liquidity Constraints and Entrepreneurial Financing in Nigeria: The Fate of Fresh Graduate Entrepreneurs. Global Journal of Management and Business Research. (13)9 : 49-57.

Pereiro, Luis E.,(2010), The Beta Dilemma in Emerging Markets, Journal of Applied Corporate Finance

Umar. (2011). Profits, Financial Leverage and Corporate Governance. SSRN Working Paper. 


\section{Exhibit}

Exhibit 1 - Interest rates, Inflation, GDP growth and macroeconomics factors (source: Viet Nam commercial banks and economic statistical bureau)

\begin{tabular}{|c|c|c|c|c|c|c|}
\hline Year & Basic rates & $\begin{array}{l}\text { Lending } \\
\text { rates }\end{array}$ & $\begin{array}{l}\text { Deposit } \\
\text { rates }\end{array}$ & Inflation & GDP & $\begin{array}{l}\text { USD/VND } \\
\text { rate }\end{array}$ \\
\hline 2012 & $\mathrm{n} / \mathrm{a}$ & $\begin{array}{l}12 \%- \\
15 \%\end{array}$ & $9 \%$ & $6,81 \%$ & $5,03 \%$ & 20.828 \\
\hline 2011 & $9 \%$ & $\begin{array}{l}18 \%- \\
22 \%\end{array}$ & $\begin{array}{l}13 \%- \\
14 \%\end{array}$ & $18 \%$ & $5,89 \%$ & 20.670 \\
\hline 2010 & $8 \%-9 \%$ & $\begin{array}{l}19 \%- \\
20 \%\end{array}$ & $\begin{array}{l}13 \%- \\
14 \%\end{array}$ & $\begin{array}{l}11,75 \% \\
\text { (Estimated at } \\
\text { Dec 2010) }\end{array}$ & $\begin{array}{l}6,5 \% \\
\text { (expected) }\end{array}$ & 19.495 \\
\hline 2009 & $7 \%$ & $9 \%-12 \%$ & $\begin{array}{l}9 \%- \\
10 \%\end{array}$ & $6,88 \%$ & $5,2 \%$ & 17.000 \\
\hline 2008 & $8,75 \%-14 \%$ & $\begin{array}{l}19 \%- \\
21 \%\end{array}$ & $\begin{array}{l}15 \%- \\
16,5 \% \\
\end{array}$ & $22 \%$ & $6,23 \%$ & 17.700 \\
\hline 2007 & $8,25 \%$ & $\begin{array}{l}12 \%- \\
15 \%\end{array}$ & $\begin{array}{l}9 \%- \\
11 \%\end{array}$ & $12,63 \%$ & $8,44 \%$ & 16.132 \\
\hline 2006 & $8,25 \%$ & & & $6,6 \%$ & $8,17 \%$ & \\
\hline 2005 & $7,8 \%$ & & & $8,4 \%$ & & \\
\hline Note & \multicolumn{6}{|c|}{$\begin{array}{l}\text { Approximately (2007: required reserves ratio at SBV is changed from } 5 \% \text { to } 10 \%) \\
\text { (2009: special supporting interest rate is } 4 \%)\end{array}$} \\
\hline
\end{tabular}

Exhibit 2 - Estimating beta results for Viet Nam Listed Hotel Companies (as of Dec 2012) (source: Viet Nam stock exchange data)

\begin{tabular}{|c|l|c|c|l|r|}
\hline $\begin{array}{c}\text { Order } \\
\text { No. }\end{array}$ & $\begin{array}{c}\text { Company } \\
\text { stock } \\
\text { code }\end{array}$ & $\begin{array}{c}\text { Equity } \\
\text { beta }\end{array}$ & $\begin{array}{c}\text { Asset beta } \\
\text { (assume debt } \\
\text { beta = 0) }\end{array}$ & \multicolumn{1}{|c|}{ Note } & \multicolumn{1}{c|}{$\begin{array}{c}\text { Financial } \\
\text { leverage (F.S } \\
\text { reports) }\end{array}$} \\
\hline 1 & DLD & 0,181 & 0,131 & $\begin{array}{l}\text { VNG as } \\
\text { comparable }\end{array}$ & $35,0 \%$ \\
\hline 2 & DXL & 0,323 & 0,250 & $\begin{array}{l}\text { SGH as } \\
\text { comparable }\end{array}$ & $28,0 \%$ \\
\hline 3 & MTC & 0,386 & 0,377 & $\begin{array}{l}\text { SGH as } \\
\text { comparable }\end{array}$ & $2,8 \%$ \\
\hline 4 & OCH & 1,085 & 0,586 & $\begin{array}{l}\text { RIC as } \\
\text { comparable }\end{array}$ & $57,5 \%$ \\
\hline 5 & SGH & 0,392 & 0,368 & & $7,9 \%$ \\
\hline & VIR & 0,325 & 0,259 & $\begin{array}{l}\text { MTC as } \\
\text { comparable }\end{array}$ & $25,2 \%$ \\
\hline 7 & VNG & 0,234 & 0,181 & & $28,4 \%$ \\
\hline & \multicolumn{1}{|l}{} & & Average & $26,38 \%$ \\
\hline
\end{tabular}


Exhibit 3 - Estimating beta results for Viet Nam Listed Entertainment Companies (as of Dec 2012) (source: Viet Nam stock exchange data)

\begin{tabular}{|c|c|c|c|c|c|}
\hline $\begin{array}{l}\text { Order } \\
\text { No. }\end{array}$ & $\begin{array}{l}\text { Company } \\
\text { stock } \\
\text { code }\end{array}$ & $\begin{array}{l}\text { Equity } \\
\text { beta }\end{array}$ & $\begin{array}{l}\text { Asset beta } \\
\text { (assume debt } \\
\text { beta }=0 \text { ) }\end{array}$ & Note & Financial leverage \\
\hline 1 & DNT & $-1,072$ & $-0,819$ & & $18,8 \%$ \\
\hline 2 & DSN & 0,703 & 0,631 & $\begin{array}{l}\text { FDT as } \\
\text { comparable }\end{array}$ & $8,2 \%$ \\
\hline 3 & GTT & 0,586 & 0,189 & $\begin{array}{l}\text { RIC as } \\
\text { comparable }\end{array}$ & $54,2 \%$ \\
\hline 4 & RIC & 1,509 & 1,216 & & $15,5 \%$ \\
\hline 5 & VPL & 0,680 & 0,184 & & $58,4 \%$ \\
\hline & & & & Average & $31,0 \%$ \\
\hline
\end{tabular}

Exhibit 4 - Statistical results of four (4) groups of 64 listed VN computer and electrical firms during/after the crisis period 2007-2011

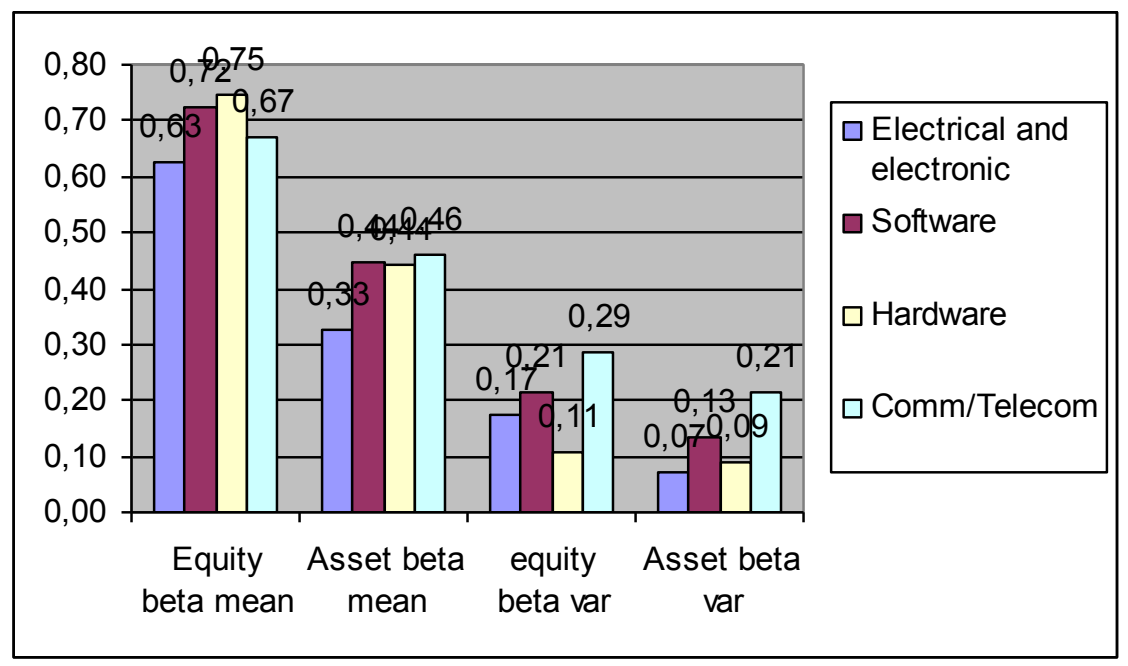

Exhibit 5 - Statistical results of three (3) groups of 103 listed construction firms during crisis period 


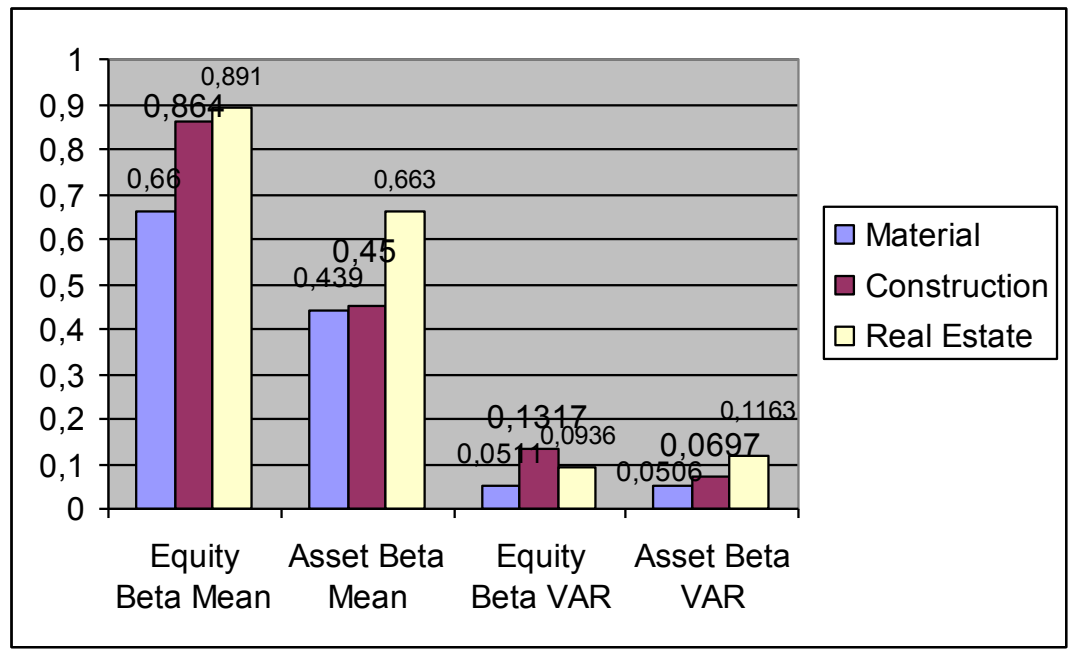

(source: Viet Nam stock exchange 2012)

Exhibit 6- VNI Index and other stock market index during crisis 2006-2010

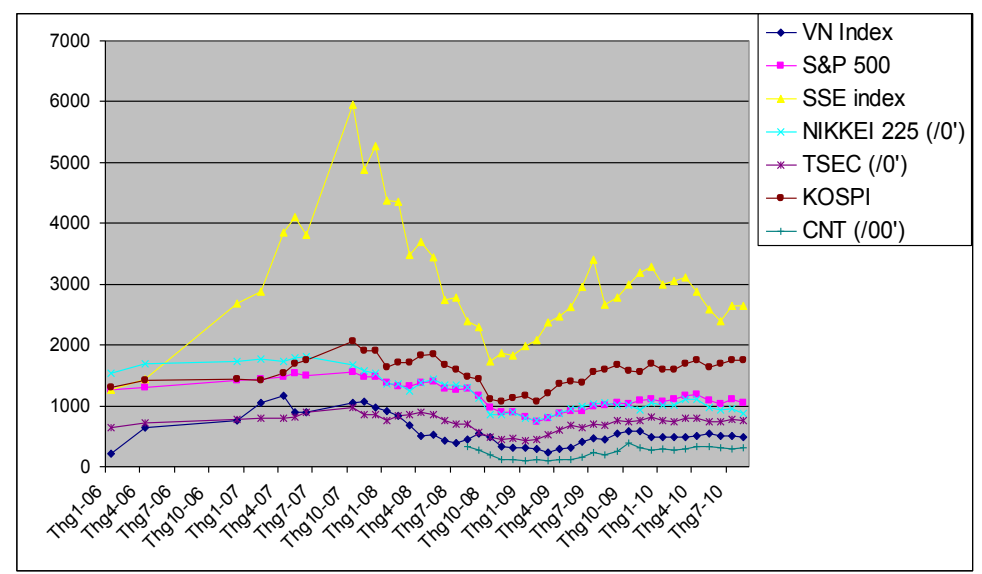

Author note: My sincere thanks are for the editorial office and Lecturers/Doctors at Banking University and International University of Japan. Through the qualitative

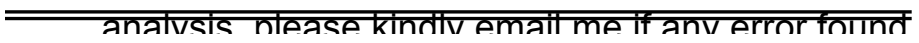

